\title{
Three new compounds with nitric oxide inhibitory activity from Tirpitzia sinensis, an ethnomedicinal plant from Southwest China
}

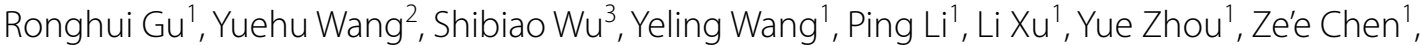 \\ Edward J. Kennelly ${ }^{1,3,4^{*}}$ and Chunlin Long ${ }^{1,2,5^{*}}$ (1)
}

\begin{abstract}
The medicinal plant Tirpitzia sinensis has been used by the Zhuang ethnic people in mountainous areas of Southwest China to stop bleeding, invigorate blood circulation, and treat inflammation and wounds. In order to further explore its traditional medicinal uses, the phytochemical constituents of this species were examined. Three new compounds, the lignan tirpitzin (1), the flavonoid tirpitzoside (2), and the furan-glycoside tirpitziol (3), along with five known compounds were isolated from the aerial part of T. sinensis for the first time. The structures of these compounds were elucidated by $1 \mathrm{D}$ and 2D NMR, LC/MS, IR spectrometric methods and compared with published data. The results of an in silico pharmacophore-based analysis showed potential targets of the new compounds, including ERBB2, IRAK4, LCK, JAK2, MAPK14, and MMP-12. These targets suggested that 1-3 may be involved with wound-healing and/or inflammation, leading to an in vitro assay of nitric oxide (NO) inhibition assays with lipopolysaccharide-induced BV-2 cells. All three new compounds displayed moderate NO inhibitory activity with the $I C_{50}$ values of $14.97 \pm 0.87,26.63 \pm 1.32$, and $17.09 \pm 2.3 \mu \mathrm{M}$, respectively.
\end{abstract}

Keywords: Tirpitzia sinensis, Linaceae, Lignans, Inflammatory, NO inhibition, Pharmacological targets,

Pharmacophore, In silico

\section{Introduction}

Tirpitzia sinensis (Hemsl.) Hallier f., known in China as "qing li chai", is a shrub or small tree in the Linaceae family. It is distributed mainly on the geologically distinct highly exposed karst limestone hills and low mountains in Guangxi, Guizhou, and Yunnan provinces of Southwest China and northern Vietnam. The branches and leaves of $T$. sinensis have been used traditionally to treat swelling, alleviate pain, and set fractures [1]. Based on our ethnobotanical survey of traditional herbs market

\footnotetext{
*Correspondence: edward.kennelly@lehman.cuny.edu;

long@mail.kib.ac.cn; long.chunlin@muc.edu.cn

${ }^{1}$ College of Life and Environmental Sciences, Minzu University of China, 27 Zhongguancun South Ave., Haidian, Beijing 100081, People's Republic of China

${ }^{3}$ Department of Biological Sciences, Lehman College, City University of New York, 250 Bedford Park Boulevard West, Bronx, New York 10468, USA

Full list of author information is available at the end of the article
}

of Jingxi County in Guangxi during 2012 and 2013, we found that the Zhuang people used T. sinensis as a medicinal plant to stop bleeding, invigorate blood circulation, and treat inflammation and traumatic injury. Flavonoids [2], cyanogenic glucosides [3], and lignans [4, 5] have been isolated from the closely related and well-studied genus Linum (Linaceae). However, no phytochemical constituents nor biological activity has been reported for T. sinensis. Therefore, as part of our continuing ethnobotanical study of Chinese folk medicinal plants, we investigated the chemical constituents of T. sinensis, and explored their potential biological activity.

Screening the bioactivity of $T$. sinensis constituents is a first step to evaluate scientifically the rationale of its traditional medicinal uses. Biological screening can be complex since the assay system to be used is not always obvious. The assays chosen can be time- and cost-intensive and the success rate may not be high [6].

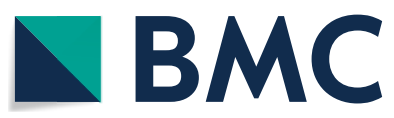

C The Author(s) 2019. This article is distributed under the terms of the Creative Commons Attribution 4.0 International License (http://creativecommons.org/licenses/by/4.0/), which permits unrestricted use, distribution, and reproduction in any medium, provided you give appropriate credit to the original author(s) and the source, provide a link to the Creative Commons license, and indicate if changes were made. The Creative Commons Public Domain Dedication waiver (http://creativecommons.org/ publicdomain/zero/1.0/) applies to the data made available in this article, unless otherwise stated. 
In recent years, pharmacophore-based parallel screening approaches have been used successfully to predict pharmacological targets of small molecules [7, 8]. Pharmacophore models are a series of three-dimensional arrangements of essential chemical features, which represent the interaction between a ligand/compound and its binding site of the receptor/pharmacological target [9].

Inflammation is the response to tissue injury, swelling and host protection [10]. NO has been reported to be involved in some inflammatory disorders, including chronic hepatitis, rheumatoid arthritis, and pulmonary fibrosis, and inhibition of NO release was considered as one of the promising ways to treat these diseases [11]. Lipopolysaccharide (LPS)-induced NO production is a common in vitro model for discovery of anti-inflammatory agents [12], which have been applied to estimate anti-inflammatory activity of new compounds [13-15]. BV-2, a microglia cell lines, applied to extensive research related to inflammation, especially in neuroinflammation.

In our research, the $n$-butanol extracts of the aerial part of $T$. sinensis was examined for the presence of midpolar anti-inflammatory compounds. Ultimately three new compounds (1-3), along with five known compounds (4-8), were isolated from the $n$-butanol extracts for the first time (Fig. 1). Only the nucleoside adenosine (5) has been reported previously in the genus Tirpitzia. We herein report the isolation and structural elucidation of three new compounds, as well as the results of a pharmacophore-based parallel screening approach to predict their potential bioactivity and pharmacological targets. Furthermore, based upon the in silico results of these new compounds, potential targets with reported effects on neuroinflammation or Alzheimer disease, such as JAK2 [16] and MAPK14 [17, 18] have been identified. Therefore, the BV-2 cell lines induced by LPS were chosen for the NO inhibition assay of the new compounds.

\section{Materials and methods}

\section{General experimental procedures}

HR-ESI-TOF-MS data were taken on a LCT premier XE TOF mass spectrometer (Waters Corp., USA). 1D NMR spectra were recorded with a Bruker Advance DRX 600 instrument operating at $600 \mathrm{MHz}$ for ${ }^{1} \mathrm{H}$ NMR and at $151 \mathrm{MHz}$ for ${ }^{13} \mathrm{C} \mathrm{NMR}$, and 2D NMR spectra were obtained with the standard Bruker software (Bruker<smiles>COc1cc([C@H]2Oc3c(OC)cc([C@@H](O[C@@H]4OC[C@](O)(CO)[C@H]4O)[C@H](O)CO)cc3[C@@H]2CO)ccc1O</smiles><smiles>COc1cc(-c2cc(=O)c3c(O)c([C@H]4O[C@H](COC5OC(C)[C@@H](O)[C@H](O)[C@H]5O)[C@@H](O)[C@H](O)[C@H]4O)c(O)cc3o2)ccc1O</smiles><smiles>COCc1cc(OC)c(OC)c(OC[C@H]2O[C@H](CO)[C@@H](O)[C@H](O)[C@H]2OC2OC3OC2[C@H](O)C3O)c1</smiles><smiles>COC(=O)c1cc(O)c2c(c1)[C@H](CO)[C@@H](c1ccc(O)c(OC)c1)O2</smiles><smiles>Nc1ncnc2c1ncn2C1OC(CO)C(O)C1O</smiles><smiles>COc1cc(CO)cc(OC)c1OC1OC(O)C2(O)OC1C(O)C(O)C2O</smiles>

6

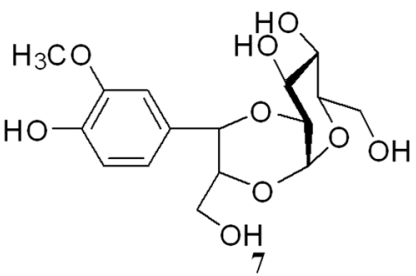

7

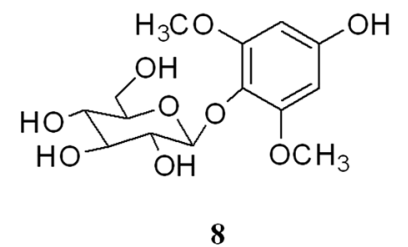

Fig. 1 The chemical structures of compounds $\mathbf{1 - 8}$ isolated from Tirpitzia sinensis 
Corp., Switzerland). IR data were tested by a Bruker VERTEX 70 spectrophotometer. Jasco P2000 (Jasco International Co., Ltd., Japan) polarimeter was used to measure optical rotations. Medium-pressure liquid chromatography (MPLC) separation was performed using a flash chromatography system equipped with pump module C-605, control unit C-620, fraction collector C-660, RI detector and UV photometer C-635 (Büchi Corp., Switzerland). Recycling high-performance liquid chromatography purifications were performed with a JAI LC-9110 NEXT (Japan Analytical Industry Co., Ltd, Japan). High-speed counter-current chromatography (HSCCC) separations were conducted with a semi-preparative TBE-300A and a preparative TBE-300B HSCCC (Shanghai Tauto Biotechnique Co. Ltd., China). Column chromatography was performed on silica gel $(100-200 \mu \mathrm{m}$ mesh, 300-400 $\mu \mathrm{m}$ mesh, Qingdao Marine Chemical Inc., China), D101 macroporous resin (Qingdao Marine Chemical Inc., China), ODS (YMC, Japan) and Sephadex LH-20 (GE Healthcare Bio-Sciences AB, USA). Preparative TLC plates with silica gel $\mathrm{GF}_{254}$ (Yantai Institute of Chemical Industry, China) was used to detect fractions and compounds by observing under UV $(254 \mathrm{~nm})$ and spraying with $10 \% \mathrm{H}_{2} \mathrm{SO}_{4}$ in $\mathrm{EtOH}$, heated until the coloration developed. MQX-200 photometer (Bio-Tek. Instrument Inc., UAS) was used to read in vitro results.

\section{Plant material}

The aerial part of $T$. sinensis were collected from Jingxi County (Guangxi Zhuang Autonomous Region, China) in June 2012, and identified by Dr. Chunlin Long (Minzu University of China). A voucher specimen (No. TS-062012) was deposited at the Laboratory of Ethnobotany, Minzu University of China.

\section{Extraction and isolation}

The air-dried aerial part of T. sinensis $(5 \mathrm{~kg})$ was powdered and extracted with 95\% $\mathrm{EtOH}$ under reflux $(3 \times 15 \mathrm{~L}$, each for $3 \mathrm{~h})$. The crude extracts were concentrated to give a residue, which was dissolved in $\mathrm{H}_{2} \mathrm{O}$ and successively partitioned with petroleum ether, EtOAc, and $n-\mathrm{BuOH}$. Subsequently, the $n-\mathrm{BuOH}$ extracts $(30 \mathrm{~g})$ was run over a macroporous resin (D101) column eluting with $\mathrm{EtOH}$ in $\mathrm{H}_{2} \mathrm{O}$ (30\%, 50\%, 70\% and 95\%, each $10 \mathrm{~L}$ ), fractions A ( $8.3 \mathrm{~g}), \mathrm{B}(7.2 \mathrm{~g}), \mathrm{C}(5.6 \mathrm{~g})$ and D (3.5 g) were obtained, respectively.

Fraction A was separated by the MPLC, equipped ODS column $(230 \times 26 \mathrm{~mm})$, and eluted with a gradient of $\mathrm{MeOH}$ in $\mathrm{H}_{2} \mathrm{O}(5-100 \%)$ to obtain five fractions (Fr. A1-Fr. A5), based on TLC profiles. Fr. A3 was subjected to Sephadex LH-20 gel column $(2.5 \times 250 \mathrm{~cm})$ in $\mathrm{MeOH} / \mathrm{H}_{2} \mathrm{O}(\mathrm{v} / \mathrm{v}=1: 1)$ to give compound $5(2.8 \mathrm{mg})$. Subfractions of Fr. A3 were purified by preparative
recycling-HPLC and eluted with $\mathrm{MeOH}$, yielded compound 3 (6.6 mg) from Fr. A3-18-20, compound 6 (29.4 mg) from Fr. A3-23-27, compound 7 (10.9 mg) and compound 8 (22.4 mg) from Fr. A3-30.

Fraction B was recombined as six parts (Fr. B1-Fr. B6), based on TLC profiles. Fr. B3 was subjected to MPLC with a $\mathrm{MeOH}$ and $\mathrm{H}_{2} \mathrm{O}$ mixture $(5-100 \%)$ as the eluent. Then, the $50 \% \mathrm{MeOH} / \mathrm{H}_{2} \mathrm{O}$ eluate was further separated by Sephadex LH-20 gel column in $\mathrm{MeOH}$ to give to Fr. B3-7, which through Sephadex LH-20 gel column in $\mathrm{MeOH}$ again and obtained Fr. B3-7 ${ }_{(28)}$. Compound 4 $(3.2 \mathrm{mg})$ was obtained from Fr. B3-7 ${ }_{(28)}$ following preparative recycling-HPLC purification with $80 \% \mathrm{MeOH} / \mathrm{H}_{2} \mathrm{O}$. Fr. B4 was separated on the HSCCC (condition: EtOAc$n \mathrm{BuOH}-\mathrm{H}_{2} \mathrm{O}$ (1:4:5), $950 \mathrm{rad} / \mathrm{min}, 2 \mathrm{~mL} / \mathrm{min}, 28^{\circ} \mathrm{C}$ ) to yield 20 fractions (Fr. B4-1 to Fr. B4-20) collecting $50 \mathrm{~mL}$ each fraction. Fr. B4-3-5 was subjected to silica gel column chromatography $(100 \times 1.5 \mathrm{~cm}, 200-300 \mu \mathrm{m}$ mesh $)$ eluted with $\mathrm{CHCl}_{3}-\mathrm{MeOH}$ gradient $(\mathrm{v} / \mathrm{v}=50: 1,30: 1$, $10: 1,5: 1,3: 1,1: 1)$ to give 40 fractions (Fr. B4-3-5(1) to Fr. B4-3-5 $(40)$ ) collecting $10 \mathrm{~mL}$ each fraction. Fr. B4-3$5_{(21-24)}$ and Fr. B4-3-5 $\left.33-36\right)$ was purified by preparative recycling-HPLC eluted with $\mathrm{MeOH}$ to give compound 1 $(8.9 \mathrm{mg}$ ) and compound $2(5.4 \mathrm{mg})$, respectively.

Tirpitin (1). Yellowish oily liquid: $[\alpha]_{\mathrm{D}}^{25}-12.3^{\circ}$ (c 0.25 , $\mathrm{CH}_{3} \mathrm{OH}$ ); IR (KBr): 3347, 2945, 2831, 1452, $1030 \mathrm{~cm}^{-1}$; ${ }^{1} \mathrm{H}$ NMR (600 MHz, $\mathrm{CD}_{3} \mathrm{OD}$ ): see Table $1 ;{ }^{13} \mathrm{C}$ NMR (151 MHz, CD $\left.{ }_{3} \mathrm{OD}\right)$ : see Table 1; HR-TOF-ESI-MS (negative-ion mode) $m / z: 547.1873[\mathrm{M}+\mathrm{Na}]^{+}$(Calcd. for $\mathrm{C}_{25} \mathrm{H}_{32} \mathrm{O}_{12} \mathrm{Na}$ : 547.1880).

Tirpitzoside (2). Yellowish oily liquid: $[\alpha]_{\mathrm{D}}^{25}-36.2^{\circ}(c 0.15$, $\mathrm{CH}_{3} \mathrm{OH}$ ); IR (KBr): 3348, 2945, 2833, 1451, $1031 \mathrm{~cm}^{-1}$; ${ }^{1} \mathrm{H}$ NMR (600 MHz, CD $\mathrm{OD}$ ): see Table $1 ;{ }^{13} \mathrm{C}$ NMR (151 MHz, CD $\left.\mathrm{CD}_{3} \mathrm{OD}\right)$ : see Table 1; HR-TOF-ESI-MS (positive-ion mode) $\mathrm{m} / z: 631.1693[\mathrm{M}+\mathrm{Na}]^{+}$(Calcd. for $\mathrm{C}_{28} \mathrm{H}_{32} \mathrm{O}_{15} \mathrm{Na}$ : 631.1639).

Tirpitziol (3). Yellowish oily liquid: $[\alpha]_{\mathrm{D}}^{25}-86.4^{\circ} \quad(c$ 0.20, $\mathrm{CH}_{3} \mathrm{OH}$ ); IR (KBr): 3363, 2946, 2833, $1031 \mathrm{~cm}^{-1}$; ${ }^{1} \mathrm{H}$ NMR (600 MHz, DMSO): see Table $1 ;{ }^{13} \mathrm{C}$ NMR (151 MHz, CD ${ }_{3} \mathrm{OD}$ ): see Table 1; HR-TOF-ESI-MS (positive-ion mode) $\mathrm{m} / z: 501.1586[\mathrm{M}+\mathrm{Na}]^{+}$(Calcd. for $\mathrm{C}_{20} \mathrm{H}_{30} \mathrm{O}_{13} \mathrm{Na}$ : 501.1584).

\section{In silico target fishing for new compounds}

Pharmacophore-based parallel screening of three new compounds isolated from $T$. sinensis were implemented by Discovery Studio 4.0 software (DS) as the following two steps: (1) Conformational optimization of tested compounds. The two-dimensional (2D) structures of compounds drawn by ChemDraw were translated to three-dimensional (3D) structures in DS. Small molecules protocol with Full Minimization algorithm was used for the 3D conformations of energy minimum of 
Table 1 NMR data of the new compounds (1-3) isolated from Tirpitzia sinensis ( $\delta$ in ppm, ${ }^{1} \mathrm{H}$ NMR $600 \mathrm{MHz} ;{ }^{13} \mathrm{C}$ NMR $151 \mathrm{MHz}$ )

\begin{tabular}{|c|c|c|c|c|c|c|}
\hline \multirow[t]{2}{*}{ Position } & \multicolumn{2}{|c|}{ Compound 1 (in $\mathrm{CD}_{3} \mathrm{OD}$ ) } & \multicolumn{2}{|c|}{ Compound 2 (in $\mathrm{CD}_{3} \mathrm{OD}$ ) } & \multicolumn{2}{|c|}{ Compound 3 (in DMSO) } \\
\hline & ${ }^{13}$ C NMR & ${ }^{1} \mathrm{H}$ NMR & ${ }^{13}$ C NMR & ${ }^{1} \mathrm{H} N M R$ & ${ }^{13}$ C NMR & ${ }^{1} \mathrm{H}$ NMR \\
\hline 1 & 134.8 & - & & & 132.9 & - \\
\hline 2 & 110.7 & $6.94(1 \mathrm{H}, \mathrm{s}$, overlapped $)$ & 166.2 & - & 152.7 & - \\
\hline 3 & 149.3 & - & 104.1 & $6.65(1 \mathrm{H}, \mathrm{s})$ & 104.5 & $6.61(1 \mathrm{H}, \mathrm{s})$ \\
\hline 4 & 147.7 & - & 184.4 & - & 138.2 & - \\
\hline 5 & 116.3 & $6.76(1 \mathrm{H}, \mathrm{d}, 8.1)$ & 164.9 & - & 104.5 & $6.61(1 \mathrm{H}, \mathrm{s})$ \\
\hline 6 & 119.9 & $6.83(1 \mathrm{H}, \mathrm{dd}, 8.1,1.3)$ & 110.5 & - & 152.7 & - \\
\hline 7 & 89.3 & $5.53(1 \mathrm{H}, \mathrm{d}, 6.2)$ & 166.2 & - & 62.9 & $4.40(2 \mathrm{H}, \mathrm{d}, 4.2)$ \\
\hline 8 & 55.5 & $3.52(1 \mathrm{H}, \mathrm{dt}, 12.6,5.3)$ & 95.6 & $6.53(1 \mathrm{H}, \mathrm{s})$ & 56.2 & $3.37(3 \mathrm{H}, \mathrm{s})$ \\
\hline 9 & 65.0 & $3.78(1 \mathrm{H}, \mathrm{m}) ; 3.83(1 \mathrm{H}, \mathrm{m})$ & 158.7 & - & 56.2 & $3.73(3 \mathrm{H}, \mathrm{s})$ \\
\hline 10 & 56.6 & $3.81(3 \mathrm{H}, \mathrm{s})$ & 105.4 & - & 56.2 & $3.73(3 \mathrm{H}, \mathrm{s})$ \\
\hline 11 & & & & & 108.5 & $5.32(1 \mathrm{H}, \mathrm{d}, 1.1)$ \\
\hline 12 & & & & & 74.0 & $3.51(1 \mathrm{H}, \mathrm{d}, 9.2)$ \\
\hline 13 & & & & & 76.6 & $3.79(1 \mathrm{H}, \mathrm{d}, 3.4)$ \\
\hline 14 & & & & & 79.3 & $5.19(1 \mathrm{H}, \mathrm{m})$ \\
\hline $1^{\prime}$ & 136.9 & - & 123.6 & - & 100.7 & $4.93(1 \mathrm{H}, \mathrm{d}, 7.3)$ \\
\hline $2^{\prime}$ & 112.7 & $6.93(1 \mathrm{H}, \mathrm{s}$, overlapped $)$ & 110.5 & $7.48(1 \mathrm{H}, \mathrm{d}, 8.1)$ & 77.1 & $3.46(1 \mathrm{H}, \mathrm{m})$ \\
\hline $3^{\prime}$ & 145.4 & - & 149.5 & - & 70.1 & $3.46(1 \mathrm{H}, \mathrm{m})$ \\
\hline $4^{\prime}$ & 149.1 & - & 152.3 & - & 64.6 & $3.19(1 \mathrm{H}, \mathrm{dq}, 10.8,3.9)$ \\
\hline $5^{\prime}$ & 129.9 & - & 116.7 & $6.94(1 \mathrm{H}, \mathrm{d}, 8.3)$ & 76.8 & $3.57(1 \mathrm{H}, \mathrm{ddd}, 11.7,4.6,2.3)$ \\
\hline $6^{\prime}$ & 117.0 & $6.92(1 \mathrm{H}, \mathrm{s})$ & 121.5 & $7.51(1 \mathrm{H}, \mathrm{dd}, 8.4,1.4)$ & 61.0 & $3.86(1 \mathrm{H}, \mathrm{d}, 9.3) ; 3.02 \mathrm{~m}$ \\
\hline $7^{\prime}$ & 75.6 & $4.62(1 \mathrm{H}, \mathrm{d}, 6.2)$ & 56.3 & $3.96(3 \mathrm{H}, \mathrm{s})$ & & \\
\hline $8^{\prime}$ & 76.1 & $3.83(1 \mathrm{H}, \mathrm{m})$ & & & & \\
\hline $9^{\prime}$ & 78.1 & $3.52(1 \mathrm{H}, \mathrm{dt}, 12.6,6.2) ; 3.92(1 \mathrm{H}, \mathrm{d}, 2.5)$ & & & & \\
\hline $10^{\prime}$ & 56.9 & $3.88(3 \mathrm{H}, \mathrm{s})$ & & & & \\
\hline $1^{\prime \prime}$ & 111.1 & $4.88(1 \mathrm{H}, \mathrm{d}, 2.6)$ & 73.5 & $4.95(1 \mathrm{H}, \mathrm{d}, 11.3)$ & & \\
\hline $2^{\prime \prime}$ & 70.7 & $3.46(1 \mathrm{H}, \mathrm{dd}, 10.4,4.2)$ & 72.1 & $3.58(1 \mathrm{H}, \mathrm{m})$ & & \\
\hline $3^{\prime \prime}$ & 80.6 & - & 82.5 & $3.42(1 \mathrm{H}, \mathrm{m})$ & & \\
\hline $4^{\prime \prime}$ & 75.1 & $3.71(1 \mathrm{H}, \mathrm{d}, 3.6) ; 3.95(1 \mathrm{H}, \mathrm{d}, 5.5)$ & 81.1 & $3.46(1 \mathrm{H}, \mathrm{m})$ & & \\
\hline $5^{\prime \prime}$ & 65.5 & $3.58(2 \mathrm{H}, \mathrm{d}, 2.9)$ & 101.9 & $3.73(1 \mathrm{H}, \mathrm{m})$ & & \\
\hline $6^{\prime \prime}$ & & & 69.8 & $3.89(1 \mathrm{H}, \mathrm{d}, 1.7) ; 3.87(1 \mathrm{H}, \mathrm{m})$ & & \\
\hline $1^{\prime \prime \prime}$ & & & 102.4 & $5.23(1 \mathrm{H}, \mathrm{s})$ & & \\
\hline $2^{\prime \prime \prime}$ & & & 72.1 & $3.87(1 \mathrm{H}, \mathrm{m})$ & & \\
\hline $3^{\prime \prime \prime}$ & & & 72.5 & $3.12(1 \mathrm{H}, \mathrm{t}, 9.3)$ & & \\
\hline $4^{\prime \prime \prime}$ & & & 69.5 & $2.57(1 \mathrm{H}, \mathrm{dd}, 9.3,6.2)$ & & \\
\hline $5^{\prime \prime \prime}$ & & & 71.8 & $3.41(1 \mathrm{H}, \mathrm{m})$ & & \\
\hline $6^{\prime \prime \prime}$ & & & 17.2 & $0.75(1 \mathrm{H}, \mathrm{d}$, overlapped $)$ & & \\
\hline
\end{tabular}

compounds. These small molecules subjected to training set based on CHARMm force field. (2) Pharmacophorebased parallel screening based on Ligand Profiler procedure. Optimized 3D conformations were submitted to Ligand Profiler procedure belonged to Pharmacophore Search module, and set the following conditions: 'Input PharmaDB Pharmacophores' was set to ALL and SHAPE was selected; 'Conformation Generation' set to FAST;
TRUE was selected in the 'Save Conformations'; then all other parameters were set to their default values in DS. After the above operations, Ligand Profiler allows testing three compounds simultaneous against all of pharmacophore models without omitting any features. Moreover, the resulting lists will display the pharmacophore hits according to fit value and the corresponding target ID, KEGG ID and target type, which help to estimate the 
potential bioactivities of the three new compounds. The overall strategy of target fishing in silico was shown in Fig. 2.

\section{Cell culture and NO inhibitory assay}

BV-2 cells, provided by the Cell Culture Center at the Institute of Basic Medical Sciences, Chinese Academy of Medical Sciences, were cultured in Dulbecco's modified Eagle's medium (DMEM/F-12) (Gibco Co., NY, USA) supplemented with $10 \%$ fetal bovine serum, $100 \mu \mathrm{g} / \mathrm{mL}$ streptomycin, and $100 \mathrm{U} / \mathrm{mL}$ penicillin. Cells were initially grown in 96-well plate (Corning Co. NY, USA) $\left(2 \times 10^{5}\right.$ cells/well $)$ and pre-treated $24 \mathrm{~h}$ later with compounds and positive control at concentration of $10 \mu \mathrm{M}, 1 \mu \mathrm{M}$ and $0.1 \mu \mathrm{M}$, respectively. The compounds and curcumin was dissolved in DMSO, and the final concentration of DMSO in medium was less than $0.1 \%$. Cells were stimulated $1 \mathrm{~h}$ later with LPS $300 \mathrm{ng} / \mathrm{mL}$ and then continue to incubate for $24 \mathrm{~h}$. Next, $100 \mu \mathrm{L}$ supernatant of culture medium from the sample was mixed with an equal volume of Griess reagent (Sigma-Aldrich, MO, USA) (1\% sulphanilamide in $5 \%$ phosphoric acid and $0.1 \% N$-naphthyl-ethylenediamine dihydrochloride) in a 96-well plate, incubated at room temperature for $10 \mathrm{~min}$. After incubation the absorbance was determined spectrophotometrically at $540 \mathrm{~nm}$. Fresh culture medium was used for blank-reading in all experiments, and the positive control was curcumin [19]. The amount of NO was calculated with reference to a sodium nitrite standard curve freshly prepared in culture medium. Cell viability controls were used to ensure that the observed NO reduction was not due to any cytotoxicity of the compounds we tested.

\section{Statistical analysis}

The inhibition percentage was calculated by the Eq. (1):

$$
\mathrm{H}=(\mathrm{ODc}-\mathrm{ODs}) /(\mathrm{ODc}-\mathrm{ODb}) \times 100
$$

In this equation, $\mathrm{H}$ is the inhibition percentage (\%), ODc, ODs and ODb are the absorbance of control, sample and blank at $540 \mathrm{~nm}$, respectively. The concentrations of compounds that gave $50 \%$ inhibiting potential $\left(\mathrm{IC}_{50}, \mu \mathrm{M}\right)$ was calculated by modified Kou type Eq. (2):

$$
\operatorname{lgIC}_{50}=\mathrm{X}_{\mathrm{m}}-\mathrm{I}\left(\mathrm{P}-\left(3-\mathbf{P}_{\mathrm{m}}-\mathbf{P}_{\mathrm{n}}\right) / 4\right)
$$

where $X_{m}$ is the lg of the maximum dose; $P$ is the sum of positive response rate; $\mathrm{P}_{m}$ is the largest positive response rate; $P_{n}$ is the smallest positive response rate; $I$ is the lg of the (maximum dose/adjacent dose) [20]. The data analyses were performed with Microsoft Excel 2013. The assays were tested in triplicate, and results were present as mean $\pm \mathrm{SD}$.

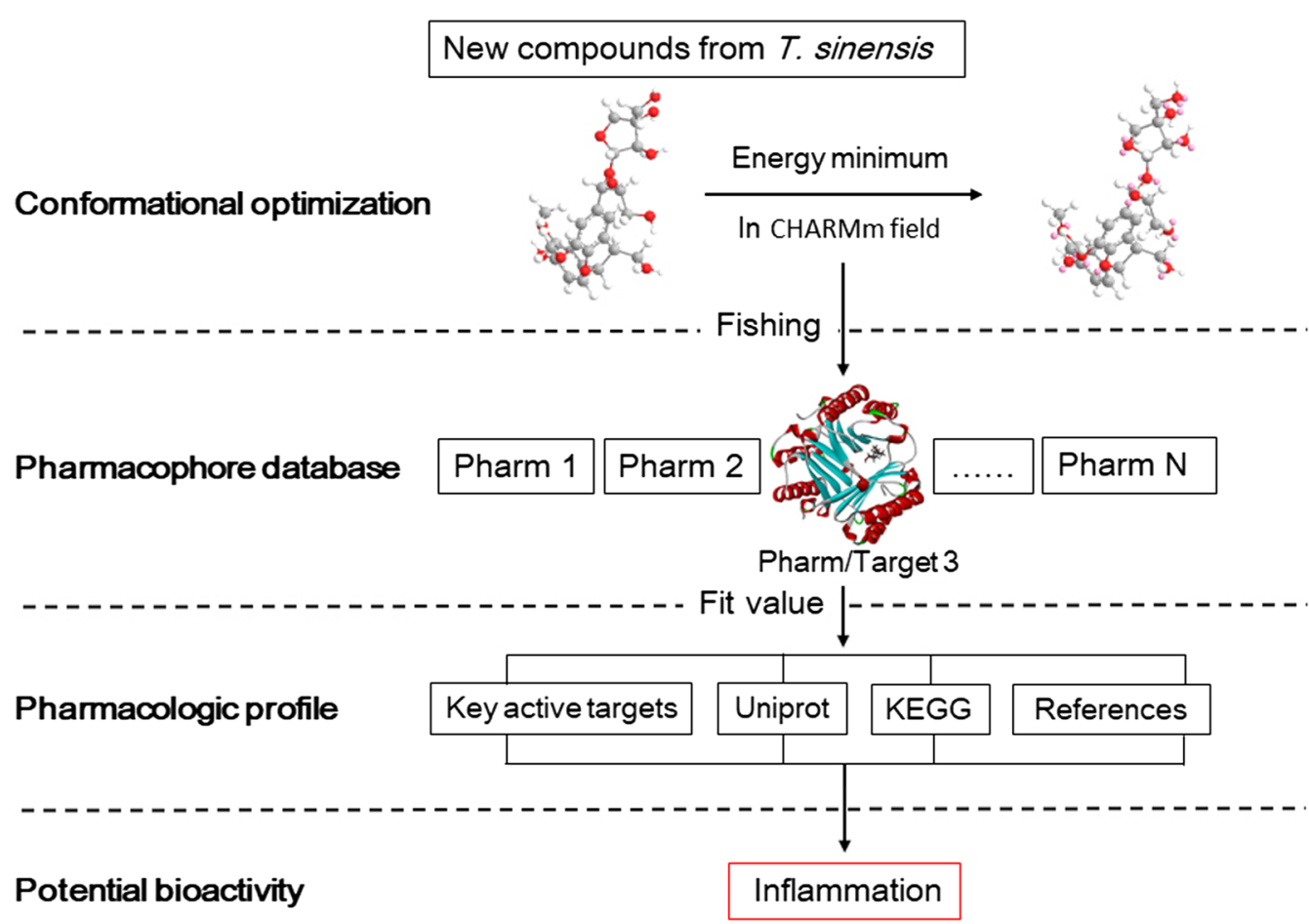

Fig. 2 The workflow of target fishing in silico 


\section{Results and discussion}

\section{Structure elucidation}

Tirpitin (1) was obtained as a yellowish oily liquid. The HR-TOF-ESI-MS spectrum of 1 supported a molecular formula of $\mathrm{C}_{25} \mathrm{H}_{32} \mathrm{O}_{12}\left(\mathrm{~m} / z 547.1873[\mathrm{M}+\mathrm{Na}]^{+}\right.$, calcd. for $\mathrm{C}_{25} \mathrm{H}_{32} \mathrm{O}_{12} \mathrm{Na}, 547.1880$ ), indicating 10 degrees of unsaturation (all spectra were shown in Additional file 1: Fig. S1). The IR spectrum showed absorptions for hydroxyl group (3347 $\left.\mathrm{cm}^{-1}\right)$, two methoxy groups $\left(2945 \mathrm{~cm}^{-1}\right.$ and $\left.2832 \mathrm{~cm}^{-1}\right)$ and an aromatic ring $\left(1451 \mathrm{~cm}^{-1}\right)$. The ${ }^{1} \mathrm{H}$ NMR spectrum (Table 1 ) exhibited a ABX system at $\delta_{\mathrm{H}} 6.94(1 \mathrm{H}, \mathrm{s}$, overlapped, $\mathrm{H}-2), 6.76(1 \mathrm{H}, \mathrm{d}, J=8.1 \mathrm{~Hz}$, $\mathrm{H}-5)$ and $6.83(1 \mathrm{H}, \mathrm{dd}, J=8.1,1.3 \mathrm{~Hz}, \mathrm{H}-6)$, as well as another $\mathrm{AB}$ system at $6.93\left(1 \mathrm{H}, \mathrm{s}\right.$, overlapped, $\left.\mathrm{H}-2^{\prime}\right)$ and $6.92\left(1 \mathrm{H}, \mathrm{s}, \mathrm{H}-6^{\prime}\right)$, indicating there are a 1,3,4,5-tetrasubstituted and a 1,3,4-trisubstituted aromatic ring. An anomeric proton at $\delta_{\mathrm{H}} 4.88(1 \mathrm{H}, \mathrm{d}, J=2.6 \mathrm{~Hz})$ correlated with the carbon at $\delta_{\mathrm{C}} 111.1$ in HSQC spectrum, which indicated that one sugar moiety may be connected via an $O$-linkage $\left[\delta_{\mathrm{C}} 111.1\left(\mathrm{C}-1^{\prime \prime}\right)\right]$. All the proton signals of the sugar unit were assigned by $\mathrm{HSQC},{ }^{1} \mathrm{H}-{ }^{1} \mathrm{H}$ COSY and HMBC spectra. Furthermore, the presence of a doublet at $\delta_{\mathrm{H}} 5.53(1 \mathrm{H}, \mathrm{d}, J=6.2 \mathrm{~Hz}, \mathrm{H}-7)$ and three characteristic carbon signals at $\delta_{\mathrm{C}} 89.3(\mathrm{C}-7), 55.5(\mathrm{C}-8)$ and 65.0 (C-9) indicated that compound 1 belongs to a group of dihydrobenzofuran-type lignans, which was confirmed by ${ }^{1} \mathrm{H}-{ }^{1} \mathrm{H}$ COSY correlations of $\mathrm{H}-7 / \mathrm{H}-8 / \mathrm{H}-9$ (Fig. 3). In the ${ }^{1} \mathrm{H}-{ }^{1} \mathrm{H}$ COSY spectrum, $\mathrm{H}-5 / \mathrm{H}-6, \mathrm{H}-7^{\prime} / \mathrm{H}-8^{\prime} / \mathrm{H}-9^{\prime}$ and $\mathrm{H}-1^{\prime \prime} / \mathrm{H}-2^{\prime \prime}$ correlations were observed. The ${ }^{1} \mathrm{H}$ NMR spectrum displayed two methoxy protons signals at $\delta_{\mathrm{H}}$ $3.87(3 \mathrm{H}, \mathrm{s})$ and $3.81(3 \mathrm{H}, \mathrm{s})$.

The ${ }^{13} \mathrm{C}$ NMR data showed 25 carbon signals of compound 1, including 2 methyls, 4 methylenes, 11 methines, and 8 quaternary carbons in the DEPT experiment. The presence of an apiofuranosyl unit was suggested by two oxygenated methylene carbons at $\delta_{\mathrm{C}}$ 75.1 and 65.6 , one oxygenated methine carbon at $\delta_{\mathrm{C}}$
70.7, one quaternary carbon at $\delta_{\mathrm{C}} 80.6$ and one anomeric carbon at $\delta_{\mathrm{C}} 111.1$ (Table 1 ), which were identified as $\alpha$ configuration based on the $J$ value-coupling constant of $\mathrm{H}-1^{\prime \prime}(J=2.6 \mathrm{~Hz})$ [21]. The HMBC correlations from proton at $\mathrm{H}-7^{\prime}\left(\delta_{\mathrm{H}} 4.62\right)$ to the carbons $\mathrm{C}-1^{\prime}$ $\left(\delta_{\mathrm{C}} 136.9\right), \mathrm{C}-2^{\prime}\left(\delta_{\mathrm{C}} 112.7\right)$, and $\mathrm{C}-6^{\prime}\left(\delta_{\mathrm{C}} 117.0\right)$ indicated that the group of $\mathrm{C}-7^{\prime} / \mathrm{C}-8^{\prime} / \mathrm{C}-9^{\prime}$ was attached to $\mathrm{C}-1^{\prime}$ of lignan skeleton (Fig. 3). Further, an HMBC correlation between the anomeric proton $\delta_{\mathrm{H}} 4.88$ and $\mathrm{C}-7^{\prime}\left(\delta_{\mathrm{C}}\right.$ $75.6)$ indicated the apiofuranosyl moiety was connected to $\mathrm{C}-7^{\prime}$ of the lignan aglycone.

When comparing the NMR data with $\left(7 R, 8 S, 7^{\prime} R, 8^{\prime} S\right)$ $1^{\prime}$-trihydroxypropyl-3'-methoxy-8-hydroxymethyl-7(4-hydroxy-3-methoxyphenyl)-7,8-dihydrobenzofuran lignan (prinsepin A) isolated from the fruit of Prinsepia uniflora Batal [22], the data for compound 1 were very similar to prinsepin A except that the apiose moiety in $\mathbf{1}$ has replaced the hydroxyl group in prinsepin $\mathrm{A}$ at $\mathrm{C}-7^{\prime}$, suggesting 1 should show the same stereochemical assignments as prinsepin $\mathrm{A}$ at $\mathrm{C}-7, \mathrm{C}-8, \mathrm{C}-7^{\prime}$ and $\mathrm{C}-8^{\prime}$. The large $J$ value $(6.2 \mathrm{~Hz})$ between $\mathrm{H}-7$ and $\mathrm{H}-8$, and $\mathrm{H}-7^{\prime}$ and $\mathrm{H}-8^{\prime}$ indicated that there are both threo diastereomers [23]. These relative stereochemical assignments for $\mathbf{1}$ can be also supported by its NOESY spectrum, the correlations of $\mathrm{H}-7 / \mathrm{H}-9 \alpha\left(\delta_{\mathrm{H}} 3.78\right)$ and $\mathrm{H}-8 / \mathrm{H}-2$ indicated that $\mathrm{H}-7$ was $\alpha$ orientation, and $\mathrm{H}-8$ was $\beta$ orientation. The relative stereochemical assignments of the apiose moiety was also confirmed by the NOESY correlations of $\mathrm{H}-1^{\prime \prime} / \mathrm{H}-7^{\prime}, \mathrm{H}-1^{\prime \prime} / \mathrm{H}-4^{\prime \prime} \beta\left(\delta_{\mathrm{H}} 3.71\right)$, and $\mathrm{H}-4^{\prime \prime} \alpha\left(\delta_{\mathrm{H}} 3.95\right) /$ $\mathrm{H}-5^{\prime \prime}$ (Fig. 3). The NOESY correlations of $\mathrm{H}-1^{\prime \prime} / \mathrm{H}-7^{\prime}$, $\mathrm{H}-2^{\prime \prime} / \mathrm{H}-8^{\prime}$, and $\mathrm{H}-4^{\prime \prime} \alpha / \mathrm{H}-5^{\prime \prime}$ also indicated that $\mathrm{H}-7^{\prime}$, $\mathrm{H}-8^{\prime}$ and the hydroxyl attached on $\mathrm{C}-3^{\prime \prime}$ are $\beta$ orientation. Based on these analyses described above, the structure 1 was elucidated as $\left(7 R^{*}, 8 S^{*}, 7^{\prime} R^{*}, 8^{\prime} S^{*}\right)-1^{\prime}$-trihydroxypropyl-3'-methoxy-8-hydroxymethyl-7-(4-hydroxy-3-methox yphenyl)-7,8-dihydrobenzofuran lignan- $7^{\prime}-\beta$-apioside as a new compound, named tirpitzin.
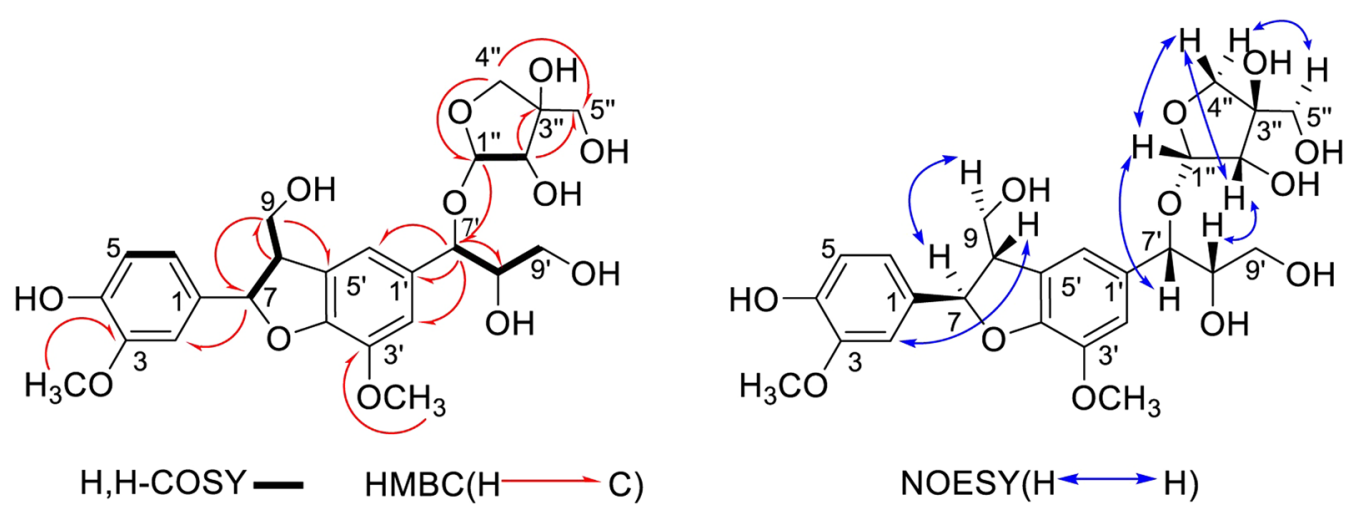

Fig. 3 Key NMR correlations of compound 1 
The molecular formula of $\mathbf{2}$ was established as $\mathrm{C}_{28} \mathrm{H}_{32} \mathrm{O}_{15} \quad\left(\mathrm{~m} / \mathrm{z} \quad 631.1693 \quad[\mathrm{M}+\mathrm{Na}]^{+}\right.$, calcd. for $\left.\mathrm{C}_{28} \mathrm{H}_{32} \mathrm{O}_{15} \mathrm{Na}, 631.1639\right)$ by HR-TOF-ESI-MS in the positive spectrum (all spectra were shown in Additional file 1: Fig. S2). The IR spectrum of 2 showed hydroxyl groups, methoxy groups and aromatic rings respectively at 3347, 2945, 2832, 1451 and $1030 \mathrm{~cm}^{-1}$. The ${ }^{1} \mathrm{H}$ NMR spectrum (Table 1) of 2 revealed an ABX system at $\delta_{\mathrm{H}} 7.51$ $\left(1 \mathrm{H}, \mathrm{dd}, J=8.4,1.4 \mathrm{~Hz}, \mathrm{H}-6^{\prime}\right), 7.48(1 \mathrm{H}, \mathrm{d}, J=1.4 \mathrm{~Hz}$, $\left.\mathrm{H}-2^{\prime}\right)$ and $6.94\left(1 \mathrm{H}, \mathrm{d}, J=8.3 \mathrm{~Hz}, \mathrm{H}-5^{\prime}\right)$, and an olefinic signal at $\delta_{\mathrm{H}} 6.65$ assigned to $\mathrm{H}-3$ position, which indicated it is a flavone skeleton [21]. Additionally, one aromatic singlet signal at $\delta_{\mathrm{H}} 6.53$, one methoxyl signal at $\delta_{\mathrm{H}}$ $3.96(3 \mathrm{H}, \mathrm{s})$, one doublet methyl signal at $\delta_{\mathrm{H}} 0.75(3 \mathrm{H}$, $\mathrm{d}$, overlapped), two anomeric proton signals at $\delta_{\mathrm{H}} 5.23$ $(1 \mathrm{H}, \mathrm{s})$ and $\delta_{\mathrm{H}} 4.95(1 \mathrm{H}, \mathrm{d}, J=11.3 \mathrm{~Hz})$ were observed as well. In the HSQC spectrum, $\delta_{\mathrm{H}} 5.23(1 \mathrm{H}, \mathrm{s})$ correlated with the carbon signal at $\delta_{\mathrm{C}} 102.4\left(\mathrm{C}-1^{\prime}\right)$ indicating that it is connected through an $O$-linkage, while the other anomeric proton $\delta_{\mathrm{H}} 4.95$ correlated with $\mathrm{C}-1^{\prime \prime}\left(\delta_{\mathrm{C}}\right.$ 73.5), suggesting it is connected to the flavone skeleton by a C-linkage [24]. The doublet methyl signal at $\delta_{\mathrm{H}} 0.75$ $(3 \mathrm{H}, \mathrm{d}$, overlapped) suggested a rhamnosyl residue in $\mathbf{2}$, which was further confirmed by the group of carbon signals at $\delta_{\mathrm{C}} 102.4,72.5,72.1,71.8,69.5$ and 17.2. The other sugar moiety was a glucopyranosyl unit for the group of carbon signals at $\delta_{\mathrm{C}} 101.9,82.5,81.1,73.5,72.1$ and 69.8. A total of 28 carbon signals of 2 was exhibited from the analysis of ${ }^{13} \mathrm{C}$ NMR, HSQC and HMBC spectra, which corresponds to one flavonoid moiety, one glucopyranosyl unit, one rhamnosyl unit and one methoxy carbon. The last aromatic proton signal at $\delta_{\mathrm{H}} 6.53(1 \mathrm{H}, \mathrm{s})$ correlates to the $\mathrm{C}-8$ position of A ring in the HSQC spectrum, and thereby indicating that there are two hydroxy-substituted at $\mathrm{C}-5$ and $\mathrm{C}-7$ of the $\mathrm{A}$ ring. In the HMBC spectrum, the correlations from $\mathrm{H}-7^{\prime}$ to $\mathrm{C}-3^{\prime}, \mathrm{H}-2^{\prime}$ to $\mathrm{C}-4^{\prime}$ and $\mathrm{C}-2$, and
$\mathrm{H}-5^{\prime}$ to $\mathrm{C}-\mathrm{1}^{\prime}$ respectively, establishing the ortho-substitution of $\mathrm{B}$ ring at $\mathrm{C}-3^{\prime}$ and $\mathrm{C}-4^{\prime}$, and methoxy located at $\mathrm{C}-3^{\prime}$ and hydroxy at $\mathrm{C}-4^{\prime}(\delta 152.3)$ for the downfield shift of $\mathrm{C}-4^{\prime}$ (Fig. 4). The HMBC correlations from $\mathrm{H}-3$ to $\mathrm{C}-1^{\prime}$, $\mathrm{C}-2, \mathrm{C}-4, \mathrm{C}-10, \mathrm{H}-8$ to $\mathrm{C}-7, \mathrm{C}-9, \mathrm{C}-10$, and $\mathrm{H}-1^{\prime \prime}$ to $\mathrm{C}-5$, confirmed that the sugar unit was attached at C-6 of the flavone aglycon.

The glucopyranosyl moiety was identified as $\beta$-Dconfiguration based on the coupling constant of $\mathrm{H}-1^{\prime \prime}$ $(J=11.3 \mathrm{~Hz})$ [25], and further supported by the NOESY spectrum. The NOESY cross-peaks (Fig. 4) between $\mathrm{H}-1^{\prime \prime}$ and $\mathrm{H}-3^{\prime \prime}, \mathrm{H}-1^{\prime \prime}$ and $\mathrm{H}-5^{\prime \prime}, \mathrm{H}-3^{\prime \prime}$ and $\mathrm{H}-5^{\prime \prime}, \mathrm{H}-2^{\prime \prime}$ and $\mathrm{H}-4^{\prime \prime}$, indicated that $\mathrm{H}-1^{\prime \prime}, \mathrm{H}-3^{\prime \prime}$ and $\mathrm{H}-5^{\prime \prime}$ were axial and $\beta$-glucose. The NOESY correlations for $\mathrm{H}-1^{\prime \prime \prime} / \mathrm{H}-2^{\prime \prime \prime}$, $\mathrm{H}-2^{\prime \prime \prime} / \mathrm{H}-3^{\prime \prime \prime}, \mathrm{H}-3^{\prime \prime \prime} / \mathrm{H}-5^{\prime \prime \prime}$, and $\mathrm{H}-4^{\prime \prime \prime} / \mathrm{H}-6^{\prime \prime \prime}$ indicated that $\mathrm{H}-1^{\prime \prime}, \mathrm{H}-3^{\prime \prime}$ and $\mathrm{H}-5^{\prime \prime}$ were $\alpha$-oriented, and $\mathrm{H}-4^{\prime \prime \prime}$, $\mathrm{H}-6^{\prime \prime \prime}$ were $\beta$-oriented. Furthermore, the obvious downfield shift of glucose methylene carbon $\left(C-6^{\prime \prime}\right)$ at $\delta_{\mathrm{C}} 69.8$ indicated the effect of glycosidation, which suggested anomeric proton of rhamnose $\delta_{\mathrm{H}} 5.23$ (s) was located at C-6" hydroxyl group of the glucosyl moiety with $\alpha$ configuration and $6 \rightarrow 1$ sequence linkage [21, 26], also supported by the NOESY correlations of $\mathrm{H}-5^{\prime \prime} / \mathrm{H}$ $6^{\prime \prime} \beta\left(\delta_{\mathrm{H}} 3.87\right)$ and $\mathrm{H}-1^{\prime \prime \prime} / \mathrm{H}-6^{\prime \prime} \alpha\left(\delta_{\mathrm{H}} 3.89\right)$. On the basis of these combined data, compound 2 was identified as $\quad 3^{\prime}$-O-methylluteolin-6-C-[1'- $\beta$-D-glucopyranosyl $(6 \rightarrow 1)-\alpha$-L-rhamnoside]. Comparison of the NMR data of 2 and known compounds, chrysoeriol-7-O[ $\alpha$-L-rhamnopyranosyl- $(1 \rightarrow 6)-\beta$-D-glucopyranoside] [27], showed similarity in flavones aglycon except for significant differences in the sugar portion. Therefore, compound $\mathbf{2}$ was established a new flavone, named tirpitzoside.

The HR-TOF-ESI-MS spectrum of $\mathbf{3}$ exhibited a molecular formula of $\mathrm{C}_{20} \mathrm{H}_{30} \mathrm{O}_{13} \quad(\mathrm{~m} / z \quad 501.1586$ $[\mathrm{M}+\mathrm{Na}]^{+}$calcd. for $\left.\mathrm{C}_{20} \mathrm{H}_{30} \mathrm{O}_{13} \mathrm{Na}, 501.1584\right)$, displaying

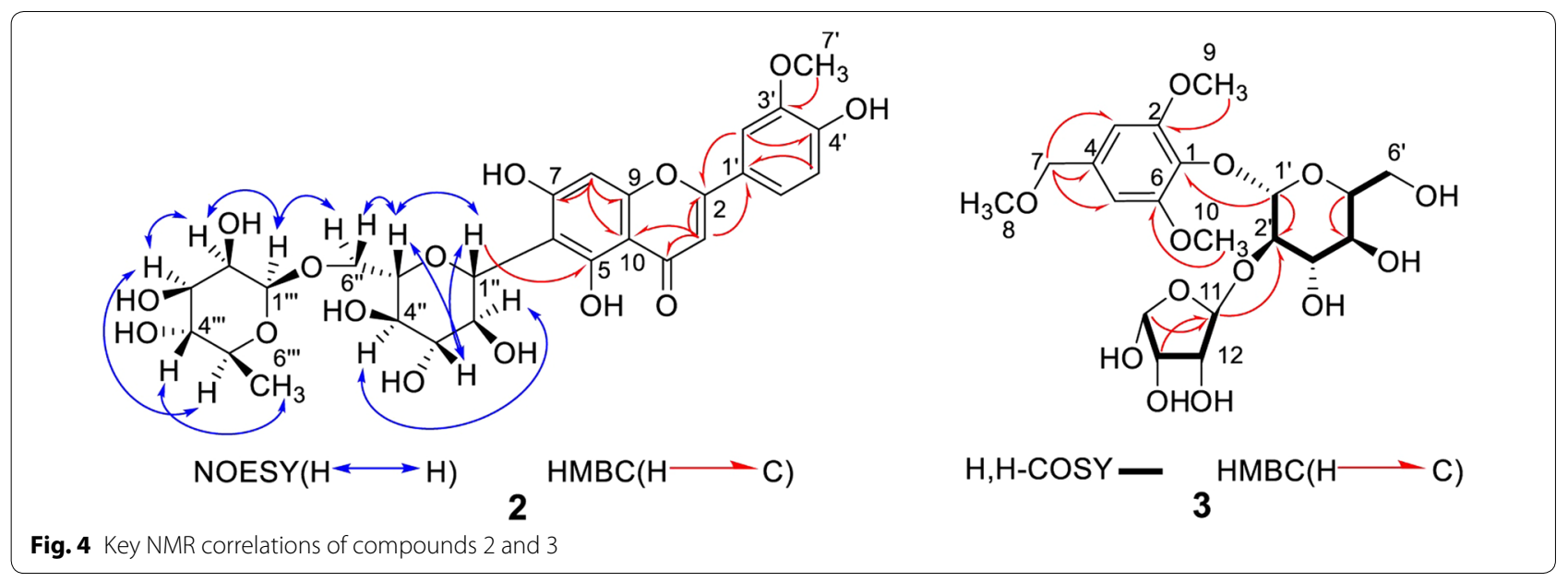


6 degrees of unsaturation (all spectra were shown in Additional file 1: Fig. S3). The IR spectrum showed absorptions for hydroxyl group $\left(3362 \mathrm{~cm}^{-1}\right)$, methoxy groups $\left(2945 \mathrm{~cm}^{-1}\right)$ and aromatic ring $\left(1030 \mathrm{~cm}^{-1}\right)$. The ${ }^{1} \mathrm{H}$ NMR spectrum of 3 indicated the existence of a 1,2,4,6-tetrasubstituted benzene ring from two singlets aromatic protons at $\delta_{\mathrm{H}} 6.6$, three methoxy signals at $\delta_{\mathrm{H}} 3.73(6 \mathrm{H}, \mathrm{s}), 3.37(3 \mathrm{H}, \mathrm{m})$. An anomeric proton signal at $\delta_{\mathrm{H}} 4.97(1 \mathrm{H}, \mathrm{d}, J=7.3 \mathrm{~Hz})$ was correlated to the carbon signal at $\delta_{\mathrm{C}} 100.7\left(\mathrm{C}-1^{\prime}\right)$ in HSQC spectrum. Moreover, the ${ }^{1} \mathrm{H}^{-}{ }^{1} \mathrm{H}$ COSY and HSQC spectra (Fig. 4) supported the assignments of $\mathrm{H}-2^{\prime}\left(\delta_{\mathrm{H}} 3.75\right), \mathrm{H}-3^{\prime}\left(\delta_{\mathrm{H}}\right.$ $3.82), \mathrm{H}-4^{\prime}\left(\delta_{\mathrm{H}} 3.41\right), \mathrm{H}-5^{\prime}\left(\delta_{\mathrm{H}} 4.19\right)$ and $\mathrm{H}-6^{\prime}\left(\delta_{\mathrm{H}} 3.54\right.$ and $\left.\delta_{\mathrm{H}} 3.35\right)$, respectively. The ${ }^{1} \mathrm{H}-{ }^{1} \mathrm{H}$ COSY displayed the correlation of $\mathrm{H}-11 / \mathrm{H}-12 / \mathrm{H}-13 / \mathrm{H}-14$ as well. In the ${ }^{13} \mathrm{C}$ NMR spectrum, the signals at $\delta \mathrm{c} 152.6,104.5$ and 56.2 were considered as three overlapping carbon signals due to their peak intensity, and were assigned as $\mathrm{C}-2 / \mathrm{C}-6, \mathrm{C}-3 / \mathrm{C}-5$, and C-9/C-10, respectively. The carbon signals (Table 1) showed a glucopyranosyl group ( $\delta$ c 100.7, 77.1, 76.8, 70.1, 64.6 and 61.0), three methoxy group $(\delta \mathrm{c} 56.2,56.2$ and 56.2$)$, an aromatic ring $(\delta \mathrm{c} 152.6,152.6,138.8,132.4,104.5$ and 104.5), and an epoxy butanol unit ( $\delta \mathrm{c} 108.5,79.3,76.6$, and 74.0$)$, corresponding to the ${ }^{1} \mathrm{H}-{ }^{1} \mathrm{H}$ COSY correlations of $\mathrm{H}-11 / \mathrm{H}-12 / \mathrm{H}-13 / \mathrm{H}-14$.

The presence of a methoxymethyl fragment was supported by the $J$ value and $\delta_{\mathrm{H}}$ of $\mathrm{H}-8\left(\mathrm{~d}, \delta_{\mathrm{H}} 3.37\right), \mathrm{H}-7$ (dd, $J=8.3,1.6 \mathrm{~Hz}, \delta_{\mathrm{H}} 4.40$ ), as well as this fragment was attached at $\mathrm{C}-4$ according to $\mathrm{HMBC}$ correlations from the proton at $\delta_{\mathrm{H}} 4.40(\mathrm{H}-7)$ to the carbon signals at $\delta \mathrm{c} 104.5$ (C-3), 138.2 (C-4) and 104.5 (C-5) (Fig. 4). Another two methoxy groups were assigned to $\mathrm{C}-2$ and $\mathrm{C}-6(\delta \mathrm{c} 152.7)$ for HMBC correlations of $\delta_{\mathrm{H}} 3.73(\mathrm{H}-9)$ to $\delta \mathrm{c} 152.7(\mathrm{C}-2)$ and $\delta_{\mathrm{H}} 3.73(\mathrm{H}-10)$ to $\delta \mathrm{c} 152.7(\mathrm{C}-6)$, respectively. The sugar residue was identified as a $\beta$-D-glucopyranosyl configuration for the large ${ }^{3} J$ value $(7.3 \mathrm{~Hz})$ of the anomeric proton [27], and its linkage was established by the HMBC cross-peaks between $\delta_{\mathrm{H}} 4.97\left(\mathrm{H}-1^{\prime}\right)$ and $\delta \mathrm{c} 132.9(\mathrm{C}-1)$. The significant downfield shift of $\mathrm{H}-11\left(\delta_{\mathrm{H}} 5.32\right)$ and $\mathrm{C}-11$ $(\delta 108.5)$ indicated the epoxy butanol unit was attached to $\mathrm{C}-2^{\prime}(\delta \mathrm{c} 77.1)$, which was also confirmed by HMBC correlations from $\mathrm{H}-11$ to $\mathrm{C}-2^{\prime}$. NMR data comparisons of 3 with known compounds, 4-methoxy-2,5-dimethylphenyl$\alpha$-L-arabinofuranosyl- $(1 \rightarrow 6)-\beta$-D-glucopyranoside [28], 3,4-dimethoxyphenyl-2-O-(3-O-methyl- $\alpha$-L-rhamnopyranosyl)- $\beta$-D-glucopyranoside [29], indicated that 3 was similar to these compounds except for the methoxymethyl group and epoxy butanol group in $\mathbf{3}$. Thus, $\mathbf{3}$ was identified as (2,6-dimethoxy-4-(methoxymethyl)phenoxy)-tetrahydro-3',4'-dihydroxy-5-(hydroxymethyl)pyran-2'-yloxy)-tetrahydrofuran-12,13,14-triol, and given the common name tirpitziol.
Using NMR and MS data, the other known compounds were identified as (2S,3R)-methyl-7-hydroxy-2-(4hydroxy-3-methoxyphenyl)-3-(hydroxymethyl)-2,3-dihydrobenzofuran-5-carboxylate (4) [30], adenosine (5) $[31,32], 3,5$-dimethoxy-benzyl alcohol 4-O- $\beta$-Dglucopyranoside (6) [33], 3-methoxy-4-hydroxy-phenylpropane-7,8-(2',1'-O- $\beta$-D-glucopyranosyl)-7,8,9-triol (7) $[34,35]$ and 2,6 -dimethoxy-4-hydroquinone-1-O- $\beta$ D-glucopyranoside (8) [36].

\section{Bioactive screening based on target fishing}

Pharmacophore-based parallel screening was conducted in silico with a program that examines each testing compound against all pharmacophore models, and then a result will be generated indicating the number of target hits and their corresponding fit value. The fit value is computed to evaluate how well the compound maps the chemical function-based features of the pharmacophore. Furthermore, the closer the fit value is to the integer 1, the higher confidence-level this value has. Therefore, we will focus on the biological properties of the predicted targets which have a higher fit value. Focusing on these targets and learning and understanding their biological roles could assist us to evaluate the potential bioactivities of the isolated new compounds and guide us to conduct related bioactive experiments. In this study, the parallel screening report found that compounds 1-3 could each fit multiple pharmacophore models (3, 146 and 218, respectively).

Compound 1 matched with three pharmacophore models, but only one of these had a fit value $>0.5$. The fit value for the pharmacophore models (ID 3pp0) of $\mathbf{1}$ is 0.5067, and this pharmacophore corresponding receptor tyrosine-protein kinase erbB2 as shown in Table 2 . It has been reported that when erbB2 was activated by heregulin- $\alpha$ in cells in a wound, the epithelial integrity will be restored more quickly [37]. In addition, erbB2 was also reported to mediate the interleukin-6 (a regulator of immune and inflammatory responses) for the activation of mitogen-activated protein kinase [38].

As for 2, we focused our studies on the following human pharmacological targets, interleukin-1-receptor-associated kinases 4 (IRAK4, pharmacophore models 2nry), tyrosine kinase (LcK, pharmacophore models 3ac3), and Janus kinase 2 (JAK2, pharmacophore models 3io7), with fit values of $0.8581,0.7986$, and 0.7695 , respectively (Table 2 ). IRAK 4 has been reported to lead to the increase of MAPK signaling pathway $N F-\kappa B$ protein, and IкB kinase, and subsequently, the activated NF- $\kappa B$ promotes the expression of the downstream target inflammatory cytokines [39]. In human pericytes, the inhibition of IRAK4 could significantly reduce myeloid differentiation primary response gene 
Table 2 Target fishing results of the new compounds (1-3) isolated from Tirpitzia sinensis

\begin{tabular}{|c|c|c|c|c|c|c|c|}
\hline Compound & Pharma-ID & Fit value & Gene-name & Uniprot-AC & KEGG-identify & Target-class & Target-class A \\
\hline 1 & $3 p p 0$ & 0.506772 & ERBB2_HUMAN & P04626 & K05083 & Receptor tyr kinase & ERBB2 \\
\hline \multirow[t]{3}{*}{2} & 2nry & 0.858086 & IRAK4_HUMAN & Q9NWZ3 & K04733 & Interleukin-1 receptors & IRAK4 \\
\hline & $3 a c 3$ & 0.798580 & LCK_HUMAN & P06239 & K05856 & Tyr protein kinases & LCK \\
\hline & $3 \mathrm{io} 7$ & 0.769459 & JAK2_HUMAN & O60674 & K04447 & Tyr protein kinases & JAK2 \\
\hline \multirow[t]{2}{*}{3} & 3zya & 0.916562 & MK14_HUMAN & Q16539 & K04441 & Ser/Thr protein kinases & MAPK14 \\
\hline & $3 e h x$ & 0.816364 & MMP12_HUMAN & P39900 & K01413 & Zinc-dependent endopeptidases & MMP-12 \\
\hline
\end{tabular}

ERBB2 means receptor tyrosine-protein kinase erbB-2; IRAK4 means interleukin-1 receptor-associated kinase 4; LCK means lymphocyte specific kinase; JAK2 means Janus kinase 2; MAPK14 means mitogen-activated protein kinase 14; MMP-12 means matrix metalloproteinase 12

88 (MyD88)-mediated inflammatory responses to kidney damage-associated molecular patterns (DAMPs) characterized by reduction in IL6 and CCL2 expression [40]. IRAK4 is known to be important in normal inflammatory reactions derived from nonbacterial or bacterial infections [41]. LcK, a tyrosine kinase, is not only a positive regulator of the mitochondrial apoptosis pathway [42], but also plays a critical role in T cell activation [43], e.g. effects in development and activation of T-cells including T-cell antigen receptor phosphorylation, which led to the production of cytokines such as IL-2 and interferon gamma and causes activation and proliferation of T-lymphocytes to generate an immune response [44]. JAK2 is involved in variety of inflammatory signaling pathways, multiple physiological and pathological regulation processes [45]. The activation of JAK2 can increase expression of high-mobility group box protein 1 , which promotes the release of cytokines such as TNF- $\alpha$ inducing the inflammatory reaction [46]. It also reported the inhibition of JAK2 can effectively block the IFNg-induced changes in microglia, suggesting that JAK2 inhibition is a potential treatment of neuroinflammation [16].

From the virtual screening results of compound 3, we focused on two pharmacological targets, mitogenactivated protein kinase 14 (MAPK14) and matrix metalloproteinase (MMP-12), corresponding pharmacophore models 3zya (fit value 0.9166) and 3ehx (fit value 0.8164 ), respectively (Table 2 ). MAPK14 (also known as MAPK p38 $\alpha$ ) is commonly expressed in various adult tissues and can mediate cellular responses to injurious stress and immune signaling [47]. The upregulated expression of MAPK14/p38 $\alpha$ protein in the brain of APP (amyloid b [A4] precursor protein)-PS1 (presenillin 1) (APP-PS1) transgenic Alzheimer mouse will lead to increase autophagy and reduce amyloid pathology, which suggests that therapeutic inhibition of MAPK14 has the potential to address the autophagic defect in Alzheimer disease [17]. Additionally, MMP-12 expression has been closely linked to tissue inflammation according to its effect in matrix remodeling, and regulated inflammatory cell trafficking [48, 49]. MMP-12 inhibition exacerbates cardiac dysfunction by disrupting the CD44-HA axis to increase and prolong inflammation and reduce neutrophil apoptosis [50]. MMP-12 showed certain effects on the proliferation of corneal epithelial cells during wound healing as well [51].

Combining proper fit value and the pivotal functions of erbB2, IRAK4, LcK, JAK2, MAPK14, and MMP-12, all of these targets are related, in part, to inflammation and/or wound healing which indicate that the isolated three new compounds from $T$. sinensis may play a role in wound healing and inflammation. Based on in silico target fishing results, we have found potential biological targets for the three new compounds and summarized some of their bioactivities with regard to inflammation, and these are consistent with the traditional medicinal knowledge of $T$. sinensis.

\section{NO production inhibitory assay}

Nitric oxide is widely accepted as an important factor of the inflammatory process [52]. NO is rapidly converted to nitrite in the presence of oxygen, the secretory activity of cells is estimated by determining nitrite concentrations after the colorimetric Griess reaction. Thus, in order to investigate whether the new compounds exhibited antiinflammation as the predicted targets showed, we performed NO production inhibitory assay in LPS-induced BV-2 cells. Compounds 1-3 all showed moderate inhibitory effects (Table 3), with $\mathrm{IC}_{50}$ values of $14.97 \pm 0.87$, $26.63 \pm 1.32$, and $17.09 \pm 2.3 \mu \mathrm{M}$ respectively, whereas the positive control (curcumin) gave an $\mathrm{IC}_{50}$ value of $4.75 \mu \mathrm{M}$. In addition, the similar types of natural products in Greiss assay have not displayed cytotoxicity at the concentrations conducted in this studies [53-55]. The in vitro results of $\mathrm{NO}$ inhibition was show the interaction of new compounds with anti-inflammatory, and thereby in part explains the traditional usage of $T$. sinensis as well. 
Table 3 NO inhibitory activity of the new compounds (1-3) from aerial part of Tirpitzia sinensis

\begin{tabular}{llll}
\hline Compound & Dose $(\boldsymbol{\mu M})$ & NO inhibition rate $(\%)$ & $\mathbf{I C}_{\mathbf{5 0}}^{\mathbf{a}}(\boldsymbol{\mu M})$ \\
\hline $\mathbf{1}$ & 0.1 & 0 & $14.97 \pm 0.87$ \\
& 1 & $11.97 \pm 0.41$ & \\
$\mathbf{2}$ & 10 & $36.47 \pm 2.37$ & $26.63 \pm 1.32$ \\
& 0.1 & 0 & \\
$\mathbf{3}$ & 1 & $7.40 \pm 1.68$ & $17.09 \pm 2.3$ \\
& 10 & $20.10 \pm 0.43$ & \\
\hline
\end{tabular}

a The concentrations of compounds that gave $50 \%$ inhibiting potential was calculated by modified Kou type equation: $\mid \mathrm{gl} \mathrm{C}_{50}=X_{\mathrm{m}}-\mathrm{I}\left(\mathrm{P}-\left(3-\mathrm{P}_{\mathrm{m}}-\mathrm{P}_{\mathrm{n}}\right) / 4\right)$. Positive control (curcumin) gave an $\mathrm{IC}_{50}$ value of $4.75 \mu \mathrm{M}$

\section{Conclusions}

Tirpitzia sinensis is an important traditional medicinal plant of the Zhuang people in Southwest China. In an attempt to validate the folk medical use of the plant, we focused our studies on its constituents and their potential bioactivities. Three new compounds (1-3), along with five known compounds, were isolated and identified from the aerial part of $T$. sinensis for the first time. The in silico results provided potential biological targets for the new compounds, and in vitro assays further demonstrated the anti-inflammatory activity. Our results, in part, help to explain the traditional usage of $T$. sinensis for treatment of wound and inflammation.

\section{Additional file}

Additional file 1. The details spectra for the identification of compound 1-3. This file includes 1D-NMR, 2D-NMR, HR-MS, IR and UV spectra of compound $\mathbf{1} \mathbf{- 3}$.

\section{Abbreviations}

NMR: nuclear magnetic resonance; 2D-NMR: two-dimension nuclear magnetic resonance; LC/MS: liquid chromatography equipped with mass spectrometry; IR: infra-red; ERBB2: receptor tyrosine-protein kinase erbB-2; IRAK4: interleukin-1 receptor-associated kinase 4; LCK: lymphocyte specific kinase; JAK2: Janus kinase 2; MAPK14: mitogen-activated protein kinase 14; MMP-12: matrix metalloproteinase 12; NO: nitric oxide; LPS: lipopolysaccharide; HR-ESI-TOFMS: high-resolution time of flight electrospray ionization mass spectrometry; MPLC: medium-pressure liquid chromatography; HSCCC: high-speed countercurrent chromatography; TLC: thin layer chromatography; UV: ultra-violet; EtOH: ethanol; EtOAc: ethyl acetate; $n$-BuOH: $n$-butanol; $\mathrm{MeOH}$ : methanol; $\mathrm{CHCl}_{3}$ : chloroform; DMSO: dimethylsulfoxide; DMEM: Dulbecco's modified Eagle's medium; OD: optical density; SD: standard deviation; IC50: 50\% inhibiting potential concentration; HSQC: heteronuclear single-quantum correlation spectroscopy; COSY: correlation spectroscopy; HMBC: heteronuclear multiplebond correlation spectroscopy; DEPT: distortionless enhancement by polarization transfer; NOESY: nuclear overhauser effect spectroscopy; TNF-a: tumor necrosis factor alpha; IFNg: interferon gamma; APP: amyloid b [A4] precursor protein; PS1: presenillin 1.

\section{Authors' contributions}

$R G, Y(I) W, C L$ and EK discussed and designed the project. RG conducted experiments and wrote draft manuscript. $R G, Y(I) W, P L, L X, C L$, and $Y(h) W$ conducted field work to investigate the traditional use of this plant. $Z C, Y Z$, and $L X$ helped with the experiments. RG, SW, Y(h)W, and PL analyzed the NMR data. RG, ZC, and $Y Z$ analyzed bioactivity data. $R G, C L$, and $E K$ revised the manuscript. All authors read and approved the final manuscript.

\section{Author details}

${ }^{1}$ College of Life and Environmental Sciences, Minzu University of China, 27 Zhongguancun South Ave., Haidian, Beijing 100081, People's Republic of China. ${ }^{2}$ Kunming Institute of Botany, Chinese Academy of Sciences, 132 Lanhei Road, Heilongtan, Kunming 650201, People's Republic of China. ${ }^{3}$ Department of Biological Sciences, Lehman College, City University of New York, 250 Bedford Park Boulevard West, Bronx, New York 10468, USA. ${ }^{4}$ Ph.D. Programs in Biology, The Graduate Center, City University of New York, 365 Fifth Ave., New York 10016, USA. ${ }^{5}$ Key Laboratory of Ethnomedicine, Minzu University of China, Ministry of Education, 27 Zhongguancun South Ave., Haidian, Beijing 100081, People's Republic of China.

\section{Acknowledgements}

We are grateful to Mr. Haibo Wu and Mr. Huahua Wang at the Minzu University of China for helping with NMR experiments and target fishing, respectively. The authors also thank Dr. Matthew Devany (Department of Chemistry, Hunter College, CUNY) for some 2D-NMR experiments. The Institute of Materia Medica, Chinese Academy of Medical Sciences and Peking Union Medical College is thanked for anti-inflammatory assays and optical rotation determinations.

\section{Competing interests}

The authors declare that they have no competing interests.

\section{Funding}

This work was supported by the National Natural Science Foundation of China (31761143001, 31070288 and 31161140345), and Ministry of Education of China through grants for Minzu University of China (B08044, 2015MDTD16C and YLDX01013), and the Ministry of Science and Technology of China (2012FY110300)

\section{Publisher's Note}

Springer Nature remains neutral with regard to jurisdictional claims in published maps and institutional affiliations.

Received: 16 November 2018 Accepted: 22 March 2019

Published online: 01 April 2019

\section{References}

1. Liu QR, Zhou LH (2008) Linaceae. In: Wu ZY, Raven PH, Hong DY (eds) Flora of China, vol 11. Science Press and Missouri Botanical Garden Press, Beijing, pp 34-40. http://foc.eflora.cn/content.aspx?Taxonld=200012413

2. Qiu SX, Lu ZZ, Luyengi L, Lee SK, Pezzuto JM, Farnsworth NR, Thompson LU, Fong HHS (1999) Isolation and characterization of flaxseed (Linum usitatissimum) constituents. Pharm Biol 37(1):1-7

3. Niedźwiedź-Siegień I (1998) Cyanogenic glucosides in Linum Usitatissimum. Phytochemistry 49(1):59-63

4. Konuklugil B, lonkova I, Vasilev N, Schmidt TJ, Windhövel J, Fuss E, Alfermann AW (2007) Lignans from Linum species of sections Syllinum and Linum. Nat Prod Res 21(1):1-6

5. Schmidt TJ, Klaes M, Sendker J (2012) Lignans in seeds of Linum species. Phytochemistry 82:89-99

6. Rollinger JM, Schuster D, Danzl B, Schwaiger S, Markt P, Schmidtke M, Gertsch M, Raduner S, Wolber G, Langer T, Stuppner H (2009) In silico target fishing for rationalized ligand discovery exemplified on constituents of Ruta graveolens. Planta Med 75(3):195-204

7. Koutsoukas A, Simms B, Kirchmair J, Bond PJ, Whitmore AV, Zimmer S, Young MP, Jenkins JL, Glick M, Glen RC, Bender A (2011) From in silico target prediction to multi-target drug design: current databases, methods and applications. J Prot 74(12):2554-2574 
8. AbdulHameed MDM, Chaudhury S, Singh N, Sun H, Wallqvist A, Tawa GJ (2012) Exploring polypharmacology using a ROCS-based target fishing approach. J Chem Inf Model 52(2):492-505

9. Rollinger JM (2009) Accessing target information by virtual parallel screening - the impact on natural product research. Phytochem Lett 2(2):53-58

10. Cuong TD, Hung TM, Lee JS, Weon KY, Woo MH, Min BS (2015) Antiinflammatory activity of phenolic compounds from the whole plant of Scutellaria indica. Bioorg Med Chem Lett 25(5):1129-1134

11. Kanwar JR, Kanwar RK, Burrow H, Baratchi S (2009) Recent advances on the roles of $\mathrm{NO}$ in cancer and chronic inflammatory disorders. Curr Med Chem 16(22):2373-2394

12. Jiang Y, Zeng KW, David B, Massiot G (2014) Constituents of Vigna angularis and their in vitro anti-inflammatory activity. Phytochemistry 107:111-118

13. Li F, Ma J, Li CJ, Yang JZ, Zhang D, Chen XG, Zhang DM (2017) Bioactive isopimarane diterpenoids from the stems of Euonymus oblongifolius. Phytochemistry 135:144-150

14. Zhao JJ, Guo YQ, Yang DP, Xue X, Liu Q, Zhu LP, Yin S, Zhao ZM (2016) Chlojaponilactone B from Chloranthus japonicus: suppression of inflammatory responses via inhibition of the NF-kB signaling pathway. J Nat Prod 79(9):2257-2263

15. Bai M, Yao GD, Ren Q, Li Q, Liu QB, Zhang Y (2018) Triterpenoid saponins and flavonoids from licorice residues with anti-inflammatory activity. Ind Crop Prod 125:50-58

16. Jones RS, Minogue AM, Fitzpatrick O, Lynch MA (2015) Inhibition of JAK2 attenuates the increase in inflammatory markers in microglia from APP/PS1 mice. Neurobiol Aging 36(10):2716-2724

17. Alam J, Scheper W (2016) Targeting neuronal MAPK14/p38a activity to modulate autophagy in the Alzheimer disease brain. Autophagy 12(12):2516-2520

18. Bachstetter $A D$, Xing B, de Almeida L, Dimayuga ER, Watterson DM, Van Eldik LJ (2011) Microglial p38a MAPK is a key regulator of proinflammatory cytokine up-regulation induced by toll-like receptor (TLR) ligands or beta-amyloid $(A B)$. J Neuroinflamm 8(1):79

19. Wang XJ, Li L, Si YK, Yu SS, Ma SG, Bao XQ, Zhang D, Qu J, Liu YB, Li Y (2013) Nine new lycopodine-type alkaloids from Lycopodium japonicum Thunb. Tetrahedron 69(30):6234-6240

20. Zhu KS, Fang WM, Chen YM, Lin SF, Chen XH (2014) TNF-related apoptosis-inducing ligand enhances vinorelbine-induced apoptosis and antitumor activity in a preclinical model of non-small cell lung cancer. Oncol Rep 32(3):1234-1242

21. Mbing JN, Missi MB, Ndongo JT, Bayiha ba Njock G, Atchade Ade T, Pegnyemb DE, Gueiffier A, Enguehard-Gueiffier C (2014) New flavonoids C-glycosides from Rhabdophyllum arnoldianum. Nat Prod Res 28(8):539-544

22. Zhou HY (2011) Studies on the chemical constituents of Nux Prinsepiae. Institute of Medicinal Plant, Chinese Academy of Medical Sciences, Beijing

23. Tezuka Y, Kasimu R, Li JX, Basnet P, Tanaka K, Namba T, Kadota S (1998) Constituents of roots of Salvia deserta SCHANG. (Xinjiang-Danshen). Chem Pharm Bull 46(1):107-112

24. Tai ZG, Cai L, Dai L, Dong LH, Wang MF, Yang YB, Cao Q, Ding ZT (2011) Antioxidant activity and chemical constituents of edible flower of Sophora viciifolia. Food Chem 126(4):1648-1654

25. Han XN, Liu CY, Liu YL, Xu QM, Li XR, Yang SL (2013) New triterpenoids and other constituents from the fruits of Benincasa hispida (Thunb.) Cogn. J Agric Food Chem 61 (51):12692-12699

26. Kumar M, Ahmad A, Rawat P, Rawat P, Khan MF, Rasheed N, Gupta P, Sathiamoorthy B, Bhatia G, Palit G, Maurya R (2010) Antioxidant flavonoid glycosides from Evolvulus alsinoides. Fitoterapia 81(4):234-242

27. Nakano H, Kawada N, Yoshida M, Ono H, Iwaura R, Tonooka T (2011) Isolation and identification of flavonoids accumulated in proanthocyanidin-free barley. J Agric Food Chemi 59(17):9581-9587

28. Ma SG, Tang WZ, Yu SS, Chen XG, Liu Y, Wang WJ, Qu J, Xu S, Ren JH, Li Y, Lü HN (2011) Four new phenolic diglycosides from the roots of Illicium oligandrum. Carbohydr Res 346(9):1165-1168

29. Pan H, Lundgren LN (1995) Phenolic extractives from root bark of Picea abies. Phytochemistry 39(6):1423-1428
30. Li WJ, Zhang ZH, Cheng XL, Liu J, He Y, Zhou C, Guo Y, Lin RC, Wang GL (2012) Two new compounds isolated from Liriope muscari. Molecules 17(8):8773-8781

31. Liang H, Bai YJ, Zhao YY, Zhang RY (1998) The chemical constituents from the roots of Bupleurum chinense DC. J Chin Pharm Sci 7(2):98-99

32. Ma YT, Qiao LR, Shi WQ, Zhang AL, Gao JM (2010) Metabolites produced by an endophyte Alternaria alternata isolated from Maytenus hookeri. Chem Nat Compd 46(3):504-506

33. Park KM, Yang MC, Lee KH, Kim KR, Choi SU, Lee KR (2006) Cytotoxic phenolic constituents of Acer tegmentosum maxim. Arch Pharm Res 29(12):1086-1090

34. Comte G, Vercauteren J, Chulia AJ, Allais DP, Delage C (1997) Phenylpropanoids from leaves of Juniperus phoenicea. Phytochemistry 45(8):1679-1682

35. Tung NH, Ding Y, Choi EM, Minh CV, Kim YH (2009) New neolignan component from Camellia amplexicaulis and effects on osteoblast differentiation. Chem Pharm Bull 57(1):65-68

36. Otsuka H, Takeuchi M, Inoshiri S, Sato T, Yamasaki K (1989) Phenolic compounds from Coix lachryma-jobi var. ma-yuen. Phytochemistry 28(3):883-886

37. Vermeer PD, Einwalter LA, Moninger TO, Rokhina T, Kern JA, Zabner J, Welsh MJ (2003) Segregation of receptor and ligand regulates activation of epithelial growth factor receptor. Nature 422(6929):322-326

38. Qiu Y, Ravi L, Kung HJ (1998) Requirement of ErbB2 for signalling by interleukin-6 in prostate carcinoma cells. Nature 393(6680):83-85

39. Kim KJ, Yoon KY, Yoon HS, Oh SR, Lee BY (2015) Brazilein suppresses inflammation through inactivation of IRAK4-NF-KB pathway in LPSInduced Raw 264.7 macrophage cells. Int J Mol Sci 16(11):27589-27598

40. Leaf IA, Nakagawa S, Johnson BG, Cha JJ, Mittelsteadt K, Guckian KM, Gomez IG, Altemeier WA, Duffield JS (2017) Pericyte MyD88 and IRAK4 control inflammatory and fibrotic responses to tissue injury. J Clin Invest 127(1):321-334

41. Medvedev AE, Lentschat A, Kuhns DB, Blanco JC, Salkowski C, Zhang S, Arditi M, Gallin Jl, Vogel SN (2003) Distinct mutations in IRAK-4 confer hyporesponsiveness to lipopolysaccharide and interleukin-1 in a patient with recurrent bacterial infections. J Exp Med 198(4):521-531

42. Samraj A, Stroh C, Fischer U, Schulze-Osthoff K (2006) The tyrosine kinase $L c k$ is a positive regulator of the mitochondrial apoptosis pathway by controlling Bak expression. Oncogene 25(2):186-197

43. Yamasaki S, Takamatsu M, Iwashima M (1996) The kinase, SH3, and $\mathrm{SH} 2$ domains of Lck play critical roles in T-Cell activation after ZAP-70 membrane localization. Mol Cell Biol 16(12):7151-7160

44. Gaba M, Singh S, Mohan C (2014) Benzimidazole: an emerging scaffold for analgesic and anti-inflammatory agents. Eur J Med Chem 76:494-505

45. Wu Y, Xu J, Xu J, Zheng W, Chen Q, Jiao D (2018) Study on the mechanism of JAK2/STAT3 signaling pathway-mediated inflammatory reaction after cerebral ischemia. Mol Med Rep 17(4):5007-5012

46. Liu H, Yao YM, Yu Y, Dong N, Yin HN, Sheng ZY (2007) Role of Janus kinase/signal transducer and activator of transcription pathway in regulation of expression and inflammation-promoting activity of high mobility group box protein 1 in rat peritoneal macrophages. Shock 27(1):55-60

47. Kim C, Sano Y, Todorova K, Carlson BA, Arpa L, Celada A, Lawrence T, Otsu K, Brissette JL, Arthur JSC, Park JM (2008) The kinase p38a serves cell type-specific inflammatory functions in skin injury and coordinates pro- and anti-inflammatory gene expression. Nat Immunol 9(9):1019-1027

48. Dean RA, Cox JH, Bellac CL, Doucet A, Starr AE, Overall CM (2008) Macrophage-specific metalloelastase (MMP-12) truncates and inactivates $E L R^{+}$CXC chemokines and generates CCL2, $-7,-8$, and -13 antagonists: potential role of the macrophage in terminating polymorphonuclear leukocyte influx. Blood 112(8):3455-3464

49. Razavian M, Bordenave T, Georgiadis D, Beau F, Zhang J, Golestani R, Toczek J, Jung JJ, Ye Y, Kim HY, Han J (2016) Optical imaging of MMP-12 active form in inflammation and aneurysm. Sci Rep 6:38345

50. Iyer RP, Patterson NL, Zouein FA, Ma Y, Dive V, de Castro Brás LE, Lindsey ML (2015) Early matrix metalloproteinase-12 inhibition worsens postmyocardial infarction cardiac dysfunction by delaying inflammation resolution. Int J Cardiol 185:198-208 
51. Lyu J, Joo CK (2005) Wnt-7a up-regulates matrix metalloproteinase-12 expression and promotes cell proliferation in corneal epithelial cells during wound healing. J Biol Chem 280(22):21653-21660

52. Calixto JB, Otuki MF, Santos AR (2003) Anti-inflammatory compounds of plant origin. Part I. Action on arachidonic acid pathway, nitric oxide and nuclear factor KB (NF-KB). Planta Med 69(11):973-983

53. Lee SR, Moon E, Kim KH (2017) Neolignan and monoterpene glycoside from the seeds of Pharbitis nil. Phytochem Lett 20:98-101
54. Yoo G, Park SJ, Lee TH, Yang H, Baek YS, Kim N, Kim YJ, Kim SH (2015) Flavonoids isolated from Lespedeza cuneata G. Don and their inhibitory effects on nitric oxide production in lipopolysaccharide-stimulated BV-2 microglia cells. Pharmacogn Mag 11(43):651-656

55. Zhou X, Gan P, Hao L, Tao L, Jia J, Gao B, Liu JY, Zheng LT, Zhen X (2014) Antiinflammatory effects of orientin-2'-O-galactopyranoside on lipopolysaccharide-stimulated microglia. Biol Pharm Bull 37(8):1282-1294
Ready to submit your research? Choose BMC and benefit from:

- fast, convenient online submission

- thorough peer review by experienced researchers in your field

- rapid publication on acceptance

- support for research data, including large and complex data types

- gold Open Access which fosters wider collaboration and increased citations

- maximum visibility for your research: over $100 \mathrm{M}$ website views per year

At BMC, research is always in progress.

Learn more biomedcentral.com/submissions 